\title{
Clostridium welchii and Bacillus cereus infection and intoxication
}

\author{
BeTTY C. HobBS \\ O.St.J., D.Sc., F.R.C.Path., Dip.Bact. \\ Food Hygiene Laboratory, Central Public Health Laboratory, \\ Colindale Avenue, London NW9 $5 \mathrm{HT}$
}

\begin{abstract}
Summary
Clostridium welchii type $A$ is a common agent of food poisoning when allowed to proliferate to large numbers in cooked foods, usually meat and poultry. The main factors of importance are survival of the spores, frequently found on raw products, through the cooking process, and possible contamination of cooked meats transferred to unclean containers; subsequent germination of spores and rapid multiplication of the vegetative cells during long slow cooling and non-refrigerated storage lead to heavy contamination. The toxin responsible is different from the soluble antigens, and its formation in the intestine is associated with sporulation.

Large numbers of $\mathrm{Cl}$. welchii of the same serological types in food and faeces is the main diagnostic factor. Important preventive measures are rapid cooling and cold storage to prevent growth.

Bacillus cereus is an aerobic sporulating organism commonly found in cereals. Outbreaks described from Europe have a different aetiology with regard to food vehicles, incubation period and symptoms from those that have been reported recently in the U.K. from fried and boiled rice. The spores survive through cooking procedures and grow out to cells which sporulate readily in the cooked food and which are assumed to produce toxin in the food. Large numbers of $B$. cereus are found in foods causing illness and, as with $\mathrm{Cl}$. welchii, the main preventive measure is inhibition of growth by quick cooling and cold storage of foods cooked ahead of requirements. A comparative table of the characteristics and clinical symptoms of $\mathrm{Cl}$. welchii and $B$. cereus is given.
\end{abstract}

\section{Clostridium welchii}

There were early reports of intestinal disturbances due to $\mathrm{Cl}$. welchii in 1895 (Klein, 1895) and 1899 (Andrewes, 1899). In $1943 \mathrm{Knox}$ and MacDonald described outbreaks of food poisoning in children after eating school meals. Gravy prepared in bulk on the previous day was heavily contaminated with anaerobic sporulating bacilli including $\mathrm{Cl}$. welchii. McClung (1945) in the U.S.A. was definite in his assertion that certain food poisoning outbreaks after meals of cooked poultry were due to $\mathrm{Cl}$. welchii. In
1948 , there was a large outbreak of intestinal disease described as enteritis necroticans in Hamburg, Germany; it was reported in a number of papers (Ernst, 1948; Schutz, 1948; Marcuse and König, 1950). The clinical and bacteriological findings were clarified in papers by Zeissler and Rassfeld-Sternberg (1949), Oakley (1949) and Hain (1949). These workers described a small outbreak of haemorrhagic enteritis in a family who had eaten tinned rabbit meat or fish; the outbreak was thought to be part of the much larger episode. The strain of $\mathrm{Cl}$. welchii isolated from food and patients survived $100^{\circ} \mathrm{C}$ for $1-4 \mathrm{hr}$ and produced much $\beta$-toxin. This strain was given the new type letter F; later it was described as a subgroup (heat-resistant) of type C (Brooks, Sterne and Warrack, 1957; Warrack, 1963; Sterne and Warrack, 1964). Hobbs et al. (1953) established Cl. welchii type $\mathrm{A}$ as a major cause of gastro-enteritis of a much milder nature than that described as enteritis necroticans by the German workers. The outbreaks reported in this paper were due to heat-resistant 'nonor $\alpha$-haemolytic $\mathrm{Cl}$. welchii'. Later McKillop (1959), Hall et al. (1963), Taylor and Coetzee (1966), and Sutton and Hobbs (1968) showed that the so-called 'heat-sensitive' strains, mostly $\beta$-haemolytic on horse blood agar, were also responsible for outbreaks. Although the spores of these strains are less resistant to heat, nevertheless they can survive cooking. Many other papers have been written on $\mathrm{Cl}$. welchit food poisoning up to the present day, when the means by which the organism causes symptoms is described.

Of the five types of $\mathrm{Cl}$. welchii A to E differentiated on the proportion of soluble antigens in each, types $\mathrm{A}, \mathrm{C}$ and $\mathrm{D}$ are pathogenic for man and types B, C, D and E affect animals. Type $A$ is further divisible into serological types; sera are obtained by inoculation of the whole organism into rabbits.

Cl. welchii type A may be isolated in small numbers from many foods both raw and cooked, and it forms a minor component of the faecal flora in most if not all healthy adults, occurring in numbers of about $10^{4} / \mathrm{g}$ of faeces. When it becomes established in the large gut, where toxin is produced, large 
numbers appear in the faecal flora. Outbreaks of enteritis necroticans due to the type $C$ strains are uncommon; they have been reported from New Guinea by Murrell et al. (1966a, b); Collee (1973) describes similar enterotoxaemic diseases produced by various types of $C l$. welchii in animals; the type $\mathrm{C}$ strains in pigs show evidence of bacterial adhesion to intestinal epithelial cells, which may explain the more serious nature of the disease caused by type $\mathrm{C}$ strains in humans as well as in animals.

The annual statistics for $\mathrm{Cl}$. welchii food poisoning in England and Wales record 47 outbreaks and approximately 1534 cases in 1969 and 32 outbreaks and 1263 cases in 1970 . The symptoms of abdominal pain, nausea and acute diarrhoea occur 8-24 hr after eating food, such as cooked meat and poultry, which has become grossly contaminated with the organism during long slow cooling periods and storage at ambient temperatures. Roast, boiled, steamed, and stewed meats and poultry, and pies and gravies are the predominant vehicles of infection, whether eaten cold or reheated. When meat is cooked in bulk, the heat gain is slow and subsequent cooling is slow. The heat drives off dissolved oxygen and the meat maintains an anaerobic environment. The heatshocked spores are activated to germinate and when the temperature drops to below $50^{\circ} \mathrm{C}$ the outgrowths of vegetative cells multiply rapidly. The so-called heat-sensitive strains of $\mathrm{Cl}$. welchii type A, usually $\beta$-haemolytic on horse blood agar and more active in production of $\alpha, \theta$ and $x$ toxins, require less heat shock for germination. Spores of these strains present on the inside of containers may grow in cooked meat foods poured into the containers.

The spores of the organisms $\mathrm{Cl}$. welchii, $\mathrm{Cl}$. botulinum and $B$. cereus can survive in food after cooking, they can be activated to germinate by the heat treatment and grow at various rates in slowly cooling food. Large numbers are assumed to be required to initiate toxin production in the intestine or to produce toxin in the foodstuff before consumption.

The characteristics of $\mathrm{Cl}$. welchii are important in relation to the food poisoning. Temperature limits for the growth of $\mathrm{Cl}$. welchii are about $25^{\circ} \mathrm{C}$ and $50^{\circ} \mathrm{C}$ and the optimum temperature for growth in cooked meat is between $43^{\circ} \mathrm{C}$ and $47^{\circ} \mathrm{C}$ (Collee, Knowlden and Hobbs, 1961). The generation time can be as short as 10-12 min (Mead, 1969). Spores of the classical strains ( $\beta$-haemolytic) of $\mathrm{Cl}$. welchii are more sensitive to heat $\left(D_{90} \circ 3-5 \mathrm{~min}\right) *$ than spores of the 'heat-resistant' strains $\left(D_{90} \circ 15-145 \mathrm{~min}\right)^{*}$ using the same sporulation medium (Roberts, 1968). It was also reported by Roberts (1968) that 30-50\% of spores of the classical strains grew without heating, and heat activation was not detected. In contrast

${ }^{*}\left(D_{90} \circ=\right.$ Decimal reduction time at $\left.90^{\circ} \mathrm{C}\right)$. less than $4 \%$ of spores of the more heat-resistant strains grew without heating, and activation was usually detected at $75-80^{\circ} \mathrm{C}$. The heat resistance, heat activation and rapid generation time are the factors which predispose this organism to survival followed by rapid multiplication in slowly cooling masses of meat and poultry. The organism is anaerobic, but not to a marked degree, nevertheless, its growth depends on anaerogenic conditions within a mass of cooked food. Large numbers (millions per gram) of viable $\mathrm{Cl}$. welchii cells in cooked foods is indicative of a health hazard.

The toxin of $\mathrm{Cl}$. welchii responsible for the food poisoning symptoms is produced in the large intestine during sporulation. The potential for sporulation in cooked foodstuffs is poor and if the toxin is formed at all it is unlikely to be detected. In the intestine, spores are readily formed and the toxin also. Ingestion of a large dose of $\mathrm{Cl}$. welchii and sporulation of the organism in vivo are important factors in the production and release of the enterotoxin. Ligated gut experiments in rabbits and lambs, those with monkeys (Duncan and Strong, 1969; Hauschild, Niilo and Dorward, 1970; Duncan and Strong, 1971) and volunteer experiments in man (Strong, Duncan and Perna, 1971) have confirmed the association between sporulation and enterotoxin production.

Hauschild (1973) refers to the toxin as enterotoxin, and he gives an excellent summary of the properties of the substance in his review. After precipitation with ammonium sulphate the toxin may be purified by gel filtration and ion exchange chromatography. The purified preparation is free of nucleic acids, fatty acids, phosphatides and reducing sugars. The u.v. absorption spectrum is maximum at $278-280$ $\mathrm{nm}$ and minimum at $250 \mathrm{~nm}$. By hydrolysis, 19 amino-acids have been demonstrated, amongst which aspartic acid, serine, leucine and glutamic acid are predominant. The substance is probably a protein of mol. wt. $36,000 \pm 4000$ with an iso-electric point of 4.3. The toxin is inactivated by pronase and $B$. subtilis protease but not by trypsin, chymotrypsin or papain. It is heat labile with a $D_{60}$ o $4 \mathrm{~min}$. The MLD for mice (i.v.) is $2000 / \mathrm{mgN}$ and lethal doses of toxin caused death within $20 \mathrm{~min}$ (Hauschild and Hilsheimer, 1971). The enterotoxin may be isolated from the supernatant fluids of the contents of ligated intestinal loops in lambs and also from extracts of cells. Intradermal injection of the enterotoxin into guinea-pigs and rabbits causes erythema around the injection site within 1-2 hr. By relating the diameter of the erythema to toxin concentration, the skin can be used for rapid and accurate assay of the enterotoxin; this test is said to be more sensitive than that of the ligated intestinal loop. Niilo (1971) showed that the erythema reaction in a guinea-pig skin was 
preceded by increased permeability of the blood capillaries around the injection site, and he suggested that the accumulation of fluid in the intestinal lumen might result from increased permeability of the blood capillaries in the intestinal wall.

Whereas the toxin ingested by volunteers or introduced into the stomachs of rhesus monkeys produces both emesis and diarrhoea, the natural illness in man is characterized by diarrhoea only from toxin produced in the intestine. The reaction from the ingestion of toxin by man and monkey can be neutralized with antiserum prepared against the enterotoxin.

Hauschild (1973) lists factors of similarity between the toxins of $\mathrm{Cl}$. welchii and Vibrio cholerae; they are both produced in vivo, induce fluid accumulation in ligated intestinal loops, inactivated by heat, inactivated by pronase but not by trypsin and are free of lipids and reducing sugars. The mode of action may be similar and it is described as enhanced adenocyclase activity and inhibited phosphodiesterase activity with a chloride and sodium imbalance.

The sequence of events in $\mathrm{Cl}$. welchii food poisoning is described neatly by Hauschild (1973) as follows: (a) ingestion of food with about $10^{6}-10^{7}$ vegetative cells of $\mathrm{Cl}$. welchii per gram; (b) multiplication and sporulation of $\mathrm{Cl}$. welchii in the small intestine; (c) production of enterotoxin in the sporulating cells; (d) release of toxin by cell lysis; (e) accumulation of fluid in the cell lumen caused by the enterotoxin whose mode of action remains to be investigated; and diarrhoea resulting from the excess fluid accumulation'. Thus symptoms are initiated by live microbial cells rather than preformed toxin and the causative enterotoxin is produced in vivo. It must be emphasized that the assay of enterotoxin in food is not required, what is needed is the quantitative estimation of live $\mathrm{Cl}$. welchii cells in incriminated foods as well as in the stools of patients.

It was pointed out by Sutton and Hobbs (1971) that a large dose of the organism is required not only to initiate growth in the intestine but also to permit survival of a fair number of organisms through the acid regions of the stomach. It appears that the metabolic changes set up by the sudden influx in the intestine of enormous numbers of $\mathrm{Cl}$. welchii from food encourages the indigenous $\mathrm{Cl}$. welchii strains to grow also.

\section{Bacillus cereus}

$B$. cereus as a food poisoning agent was described by Hauge in 1950 and 1955; cornflour sauce precooked to eat with fruit at picnics was responsible for outbreaks occurring in Norway. Christiansen, Koch and Madelung (1951) described an outbreak due to cornflour pudding. Clarenburg and Kampelmacher (1957) in Holland, Nikodemusz (1958) in Hungary,
Midura et al. (1970) in the U.S.A., Pivovarov et al. (1970) in the U.S.S.R., von Ludwig (1971) in Germany and Fredette and Planté (1971) in Canada, all described outbreaks of food poisoning due to $B$. cereus in which the incubation time and symptoms were similar to those for $\mathrm{Cl}$. welchii food poisoning. Recent reviews include those of Goepfert, Spira and Kim (1972) and Goepfert et al. (1973). A wide variety of foods have been implicated in these outbreaks including soup, cooked meat, cooked potatoes and vegetables, vanilla sauce, cornflour pudding, fried rice and soya sauce.

From 1971 onwards U.K. reports have described several incidents of food poisoning associated with fried rice from Chinese restaurants. However, the incubation period and symptoms are different from those described hitherto. Vomiting occurs about 1-6 $\mathrm{hr}$ following a meal, sometimes there is diarrhoea a few hours later. Fried or boiled rice is the only food common to those affected. Samples of cooked rice showed high counts of $10^{7}-10^{8} / \mathrm{g}$ of $B$. cereus. Neither Staphylococcus aureus nor staphylococcal enterotoxin were detected in samples of food examined carefully because of the similarity of incubation time and symptoms with staphylococcal enterotoxin food poisoning.

$B$. cereus is widely distributed in cereals and other dried foods, and in dairy products it is a common spoilage organism. Spores are readily formed in the vegetative cells; they may survive cooking procedures and grow out in the rice. The common fault is to allow large quantities of boiled rice to drain overnight at ambient kitchen temperature. The following day the rice may be fried quickly with beaten up egg which, if not freshly prepared, may also be highly contaminated with a miscellaneous collection of bacteria. Often the fried rice is kept warm until customers arrive in the shop to take away portions. The large numbers of $B$. cereus isolated from samples of fried rice indicate that neither the organism nor the toxin are destroyed in the quick passage through hot fat described as frying.

A few years ago Nygren (1962) suggested that the symptoms of both $\mathrm{Cl}$. welchii and $\mathrm{B}$. cereus were due to the liberation of phosphorylcholine from lecithin by the phospholipase $\mathrm{C}$ enzyme of these organisms, but Stark and Duncan (1972) and Hauschild (1973) have shown that $\mathrm{Cl}$. welchii food poisoning is due to an enterotoxin separate and distinct from phosphorylcholine.

Similar data described by Goepfert and summarized in 1973 indicate that $B$. cereus also produces an enterotoxic substance that can be readily differentiated from lecithinase. Goepfert (1973) describes this toxic substance as 'protein in nature actively synthesized and secreted during logarithmic growth, causing fluid to accumulate in ligated ileal segments 
in the rabbit and inducing increased intestinal motility and overt diarrhoea upon oral administration to rhesus monkeys'. The toxin he says is 'thermo-labile, susceptible to various proteolytic enzymes and antigenic'; approximately $80 \%$ of the B. cereus strains tested by him, presumably mostly from European sources, have shown evidence of producing this enterotoxic substance. The work in Goepfert's laboratory suggests that there are two antigenically distinct enterotoxins (not produced by the same strain of B. cereus).

Among other Bacillus species tested by Goepfert et al. (1973), B. thuringiensis was observed to give similar pathological symptoms in laboratory animal models. They think it is unlikely that the enterotoxin factors are related to the parasporal crystal inclusion body in the insect pathogen. The enterotoxic activity of a culture filtrate of $B$. thuringiensis was neutralized by antiserum produced against a culture filtrate of $B$. cereus.

The work on $B$. cereus is in its early days. Explanation is needed for the differences in incubation time and clinical symptoms between outbreaks in Eastern Europe and other places and outbreaks recently associated with cooked rice dishes in the United Kingdom (Public Health Laboratory Service, 1972, 1973), Australia (J. Taplin, personal communication), and Canada (Lefebvre et al., 1973). Furthermore, volunteer experiments in man are inevitable as final proof of the role of the organism in food poisoning and to fulfil Koch's postulates. The isolation of the organism from faecal samples of patients is somewhat irregular and may depend on the freshness of the stool sample.

Work to be published by Gilbert, Stringer and Peace (in press) indicates an optimum temperature for growth of $B$. cereus between 30 and $37^{\circ} \mathrm{C}$. The maximum temperature for growth was thought to be between 43 and $48^{\circ} \mathrm{C}$, and the minimum temperature was found to fall between 10 and $15^{\circ} \mathrm{C}$.

The heat resistance of $B$. cereus spores during the process of boiling is of practical concern in survival of the organism during cooking. Studies carried out in 1972 (Gilbert, Stringer and Peace, personal communication) suggest that whereas $30 \%$ of the spores of one strain of $B$. cereus were capable of surviving at $95^{\circ} \mathrm{C}$ in aqueous suspension after 20-25 min, only $0.0001 \%$ of the spores of another strain were able to germinate under the same conditions; there was a similar pattern of survival in rice allowed to stand after boiling. The growth rate of the two strains tested was also different. There was a rapid fall in counts after frying but the subsequent increase in numbers after storage at room temperature was further evidence of the marked heat resistance and survival properties of the $B$. cereus spores. Spores of both strains of $B$. cereus tested showed a wide range of heat resistance and when germinated large numbers of spores rapidly appeared in the vegetative cells. In a similar way to $C l$. welchii the significance of $B$. cereus in cooked foods depends on the numbers present. Colony counts below $10^{6} / \mathrm{g}$ are

TABLE 1. Characteristics in relation to food poisoning

\begin{tabular}{lll}
\hline & Clostridium welchii & \multicolumn{1}{c}{ Bacillus cereus } \\
\hline Prevalence & Common & Common \\
Growth & $\begin{array}{l}\text { Food, faeces, soil, dust } \\
\text { Cereals, soil, dust } \\
\text { meat and poultry }\end{array}$ & $\begin{array}{l}\text { Aerobic growth in rice } \\
\text { and other cereals }\end{array}$ \\
Generation time & $10-12 \mathrm{~min}$ & 27 min \\
Optimum temperature & $43-47^{\circ} \mathrm{C}$ & $30^{\circ} \mathrm{C}$ \\
Minimum & $15-20^{\circ} \mathrm{C}$ & $10-12^{\circ} \mathrm{C}$ \\
Maximum & $50^{\circ} \mathrm{C}$ & $48^{\circ} \mathrm{C}$ \\
Sporulation & Poor in food & Good in food \\
& Good in intestine & \\
Heat resistance $\mathrm{D}_{100}$ & Less than 1 min to & 1 min to $7 \cdot 5$ min \\
& 17 min & \\
Mechanism & Toxin liberated in & Toxin produced in food \\
intestine & \\
Incubation & $12-18$ hr & 2 hr (15 hr) \\
Symptoms & Diarrhoea and pain & Vomiting \\
(vomiting) & (diarrhoea and pain) \\
Dose required & Large numbers of & Large numbers of \\
organisms & organisms plus toxin \\
Stool & Large numbers of & Variable number of \\
organisms & organisms \\
Prevention & Stop growth in food & Stop growth in food \\
\hline
\end{tabular}

(From Hobbs, 1973.) 
probably of little significance but counts above $10^{6} / \mathrm{g}$ in cooked foods stored at ambient temperatures may indicate that food poisoning could occur.

The foods responsible for outbreaks both of $\mathrm{Cl}$. welchii and $B$. cereus food poisoning are invariably those which have been prepared ahead of requirements. Their bulk and the general lack of proper facilities for cooling and refrigeration enable and encourage the organisms to grow. Sutton, Kendall and Hobbs (1972) demonstrated that spores of $\mathrm{Cl}$. welchii survived in large and small portions of beef cooked in conventional and moist air Rapidaire ovens, whereas vegetative cells were destroyed. When the cooked meats were cooled at room temperature growth occurred, and some multiplication took place in the centre of large roasts even when they were cooled under refrigeration. Dehydrated foods frequently contain bacterial spores which may be added to foods at a late stage of cooking, for example, spices and pepper in curries and other socalled hot foods. Thus even small numbers of $\mathrm{Cl}$. welchii spores in dehydrated foods may be a hazard when these foods are used as ingredients.

Food hygiene education should stress the facts that raw foods are frequently contaminated with food poisoning organisms before they even reach the kitchen, that bacterial spores are often present and that they can survive boiling and other methods of cooking with the exception of steam under pressure. The outgrowth of $\mathrm{Cl}$. welchii spores occurs in the absence of air inside rolled joints, poultry carcasses, pastry casings and at the bottom of stews; B. cereus spores will grow out under aerobic conditions in masses of food such as rice, cooked and left wet for some hours at ambient temperature. Long, slow cooling and non-refrigerated storage provide ideal conditions for bacterial multiplication. A better understanding of these facts, provision by architects of facilities for rapid cooling of foods and sufficient cold storage for large bulks of food would help to prevent both $\mathrm{Cl}$. welchii and $\mathrm{B}$. cereus food poisoning. Table 1 is quoted from Hobbs (1973) and shows the relevant characteristics of the organisms $\mathrm{Cl}$. welchii and $B$. cereus.

\section{References}

ANDREWES, F.W. (1899) On an outbreak of diarrhoea in the wards of St Bartholomew's Hospital, probably caused by infection of rice pudding with Bacillus enteritides sporogenes. Lancet, i, 8.

Brooks, M.E., Sterne, M. \& Warrack, G.H. (1957) A reassessment of the critera used for type differentiation of Clostridium perfringens. Journal of Pathology and Bacteriology, 74, 185.

Christiansen, O., Koch, S.O. \& Madelung, P. (1951) Et udbrud af levnedsmiddelforgiftning forarsoget af Bacillus cereus. Nordisk Veterinärmedicin, 3, 194.

Clarenburg, A. \& Kampelmacher, E.H. (1957) Bacillus cereus als oorzaak van voedselvergiftiging. Voeding, 18, 384.
Collee, J.G., Knowlden, J.A. \& Hobbs, B.C. (1961) Studies on the growth, sporulation and carriage of Clostridium welchii with special reference to food poisoning strains. The Journal of Applied Bacteriology, 24, 326.

ColleE, J.G. (1973) The potential enteropathogenicity of Clostridium welchii ( $\mathrm{Cl}$. perfringens) in man. 1st International Congress for Bacteriology, Jerusalem. Abstracts, 1, 158.

Duncan, C.L. \& Strong, D.H. (1969) Experimental production of diarrhoea in rabbits with Clostridium perfringens. Canadian Journal of Microbiology, 15, 765.

Duncan, C.L. \& Strong, D.H. (1971) Clostridium perfringens type A food poisoning. I. Response of the rabbit ileum as an indication of the enteropathogenicity of strains of Clostridium perfringens in monkeys. Infection and Immunity, 3, 167.

ERNST, O. (1948) Epidemiologische Beitrag zu Enteritis necroticans. Deutsche Gesundheitswesen, 3, 262.

Fredette, V. \& Planté, C. (1971) Episode montrẻalais d'empoisonnement alimentaire à Bacillus cereus. L'Institut de Microbiologie et d'Hygiene de l'Université de Montréal, 100, 1943.

Goepfert, J.M., Spira, W.M., Glatz, B.A. \& Kim, H.U. (1973) Pathogenicity of Bacillus cereus. In: Proceedings of the 8th International Symposium. The Microbiological Safety of Food, p. 69. London: Academic Press.

Goepfert, J.M., SPIRA, W.M. \& KiM, H.U. (1972) Bacillus cereus: food poisoning organism. A review. Journal of Milk and Food Technology, 35, 213.

GoEPferT, J.M. (1973) Pathogenicity patterns in Bacillus cereus food-borne disease. 1st International Congress for Bacteriology, Jerusalem. Abstracts, 1, 140.

HaIN, E. (1949) Origin of Clostridium welchii type F infection. British Medical Journal, 1, 271.

Hall, H.E., Angelotti, R., Lewis, K.H. \& Foter, M.J. (1963) Characteristics of Clostridium perfringens strains associated with food and food-borne disease. The Journal of Bacteriology, 85, 1094.

Hauge, S. (1950) Matforgiftninger fremkalt au Bacillus cereus. Nordisk Hygienisk Tidskrift, 31, 189.

HaUge, S. (1955) Food poisoning caused by aerobic sporeforming bacilli. The Journal of Applied Bacteriology, 18, 591.

Hauschild, A.H.W. (1973) Food poisoning by Clostridium perfringens. Canadian Institute of Food Science and Technology, 6, 106.

Hauschild, A.H.W. \& Hilsheimer, R. (1971) Purification and characteristics of the enterotoxin of Clostridium perfringens type A. Canadian Journal of Microbiology, 17, 1425.

Hauschild, A.H.W., Nillo, L. \& Dorward, W.J. (1970) Response of ligated intestinal loops in lambs to an enteropathogenic factor of Clostridium perfringens type $\mathrm{A}$. Canadian Journal of Microbiology, 16, 339.

HoBss, B.C. (1973) Food poisoning in England and Wales. In: Proceedings of the 8th International Symposium. The Microbiological Safety of Food, p. 129. London: Academic Press.

Hobbs, B.C., Smith, M.E., OAKley, C.L., WarRack, G.H. \& Cruickshank, J.C. (1953) Clostridium welchii food poisoning. Journal of Hygiene, 51, 75.

KLEIN, E. (1895) Ueber einen pathogenen anäeroben Darm bacillus, Bacillus enteritides sporogenes. Zentralblatt für Bakteriologie, Parasitenkunde, Infektionskrankheiten und Hygiene. I. Abteilung: Originale, 18, 737.

KNOX, R. \& MacDonald, E.K. (1943) Outbreaks of food poisoning in certain Leicester institutions. Medical Officer, 69, 21.

Lefebvre, A., Gregoire, C.A., Brabant, W. \& Todd, E. (1973) Suspected Bacillus cereus food poisoning. Epidemiological Bulletin, 17, 108. 
LudwiG, K. voN (1971) Bacillus cereus als Ursache einer lebensmittel Intoxikation. Archiv für Lebensmittel Hygiene, 5, 104.

MarCuSE, K. \& KöNig, I. (1950) Bakteriologische Befunde bei Jejunitis necroticans. Zentralblatt für Bakteriologie, Parasitenkunde, Infektionskrankheiten und Hygiene. I. Abteilung, Originale, 156, 107.

MCClung, L.S. (1945) Human food poisoning due to growth of Clostridium perfringens $(\mathrm{Cl}$. welchii) in freshly cooked chicken: preliminary note. The Journal of Bacteriology, 50, 229.

MCKILlop, E.J. (1959) Bacterial contamination of hospital food with special reference to Clostridium welchii food poisoning. Journal of Hygiene, 57, 31 .

MEAD, G.C. (1969) Growth and sporulation of Clostridium welchii in breast and leg muscle of poultry. The Journal of Applied Bacteriology, 32, 86.

Midura, T., Gerber, M., Wood, R. \& Leonard, A.R. (1970) Outbreak of food poisoning caused by Bacillus cereus. Public Health Reports, 85, 45.

Murrell, T.G.C., Egerton, J.R., Rampling, A., Samels, J. \& WAlker, P.D. (1966b) The ecology and epidemiology of the pig-bel syndrome in man in New Guinea. Journal of Hygiene, 64, 375.

Murrell, T.G.C., Roth, L., Egerton, J., Samels, J. \& Walker, P.D. (1966a) Pig-bel: enteritis necroticans. A study in diagnosis and management. Lancet, i, 217.

Nikodemusz, I. (1958) Bacillus cereus als Ursache von lebensmittel Vergiftungen. Zeitschrift für die Gesamte Hygiene und Ihre Grenzgebiete, 145, 335.

NilLo, L. (1971) Mechanism of action of the enteropathogenic factor of Clostridium perfringens type A. Infection and Immunity, 3, 100.

Nygren, B. (1962) Phospholipase C-producing bacteria and food poisoning. Acta Pathologica et Microbiologica Scandinavica, Supplement, 160, 88.

OAKLEY, C.L. (1949) The toxins of Clostridium welchii type F. British Medical Journal, 1, 269.

Pivovarov, Y.P., Sidorenko, G.I., TKaChenko, A.V., Goldberg, E.S., AKimov, A.M., Volkova, R.S. \& Shelakova, V.V. (1970) Bacillus cereus as causative organism of food poisoning in man. Voprosy Pitaniya, 29, 25 .
Public Health laboratory Service (1972) Food poisoning associated with Bacillus cereus. British Medical Journal, 1, 189.

Public Health Laboratory Service (1973) Bacillus cereus food poisoning. British Medical Journal, 11, 647.

ROBERTS, T.A. (1968) Heat and radiation resistance and activation of spores of Clostridium welchii. The Journal of Applied Bacteriology, 31, 133.

Schutz, F. (1948) Darmbrand: neue Erkenntnisse zu seiner Pathogenese und Therapie. Deutsche Medizinische Wochenschrift, 73, 176.

Stark, R.L. \& Duncan, C.L. (1972) Purification and biochemical properties of Clostridium perfringens Type A enterotoxin. Infection and Immunity, 6, 662.

Sterne, M. \& Warrack, G.H. (1964) The types of Clostridium perfringens. Journal of Pathology and Bacteriology, 88, 279.

Strong, D.H., Duncan, C.L. \& Perna, G. (1971) Clostridium perfringens type A food poisoning. II. Response of the rabbit ileum as an indication of enteropathogenicity of strains of Clostridium perfringens in human beings. Infection and Immunity, 3, 171.

Sutron, R.G.A. \& HobBs, B.C. (1968) Food poisoning caused by heat sensitive Clostridium welchii. A report of five recent outbreaks. Journal of Hygiene, 66, 135.

Sutton, R.G.A. \& HobBs, B.C. (1971) Resistance of vegetative cells of Clostridium welchii to low pH. Journal of Medical Microbiology, 4, 539.

Sutton, R.G.A., Kendall, M. \& Hobrs, B.C. (1972) The effect of two methods of cooking and cooling on Clostridium welchii and other bacteria in meat. Journal of Hygiene, 70, 415 .

TAYLOR, C.E.D. \& CoetzeE, E.F.C. (1966) Range of heat resistance of Clostridium welchii associated with suspected food poisoning. Monthly Bulletin of the Ministry of Health and the Public Health Laboratory Service, 25, 142.

WARRACK, G.H. (1963) Some observations on the typing of Clostridium perfringens. Bulletin de l'Office International des Epizooties, 59, 1393.

Zeissler, J. \& RASSFeld-STERnberg, L. (1949) Enteritis necroticans due to Clostridium welchii type F. British Medical Journal, 1, 267. 